\title{
Ocular lesions in sickle cell disease patients from Bahia, Brazil
}

\author{
Lesões oculares em pacientes com doença \\ falciforme da Bahia, Brasil
}

Dayse Cury ${ }^{1}$, Ney Boa-Sorte ${ }^{2}$, Isa Menezes Lyra ${ }^{3}$, Angela Dias Zanette ${ }^{4}$, Humberto Castro-Limat ${ }^{5}$, Bernardo Galvão-Castro ${ }^{6}$, Marilda Souza Gonçalves

\begin{tabular}{l}
\hline ABSTRACT \\
Objective: The present study aims to describe ocular alterations in sickle cell disease \\
patients in Bahia, a Northeast state, with the highest prevalence of the disease in Brazil. \\
Methods: We carried out a cross-sectional study in a group of 146 (292 eyes) sickle cell \\
disease patients (90 HBSS and 56 HBSC). Ophthalmologic examination including indirect \\
binocular ophthalmoscopy was performed. Examination was completed by fluorescein \\
angiography to detect retinal lesions. Results:The most frequent ocular lesions identified \\
were "vascular tortuosity" and "black sunburst". Proliferative retinopathy was found in \\
$22(12.2 \%)$ eyes of HBSS patients and 25 (22.3\%) eyes of HBSC patients (OR=2.06; \\
CI95\%: $1.5-4.06$, p=0.022); Its frequency was higher among HBSS patients aged $20-39$ \\
years, while in HBSC patients, it peaked after 40 years (35.7\% and 42.8\%) and dropped \\
sharply afterwards. Conclusion: Proliferative retinopathy was described as early as 10 \\
years of age in both patients groups. Proliferative sickle retinopathy can result in blindness \\
and the knowledge of the most prevalent ocular alterations and age risk will be important \\
to establish a protocol of ophthalmologic follow-up,in order to prevent a severe visual loss \\
and increase patient's life quality.
\end{tabular}

Keywords: Anemia, sickle cell; Hemoglobin SC disease; Eye injuries; Retinal diseases

\footnotetext{
${ }^{1}$ Instituto Brasileiro de Oftalmologia e Prevenção a Cegueira (IBOPC) Salvador (BA), Brasil; Escola de Medicina e Saúde Pública da Bahia; Fundação para o Desenvolvimento das Ciências da Bahia - EBMSP/FBDC - Salvador (BA), Brasil;

${ }^{2}$ Escola de Medicina e Saúde Pública da Bahia/Fundação para o Desenvolvimento das Ciências da Bahia - EBMSP/FBDC - Salvador (BA), Brasil; Centro de Pesquisas Gonçalo Moniz - Fundação Oswaldo Cruz- (CPqGM-Fiocruz)- Salvador (BA), Brasil;

${ }^{3}$ Fundação de Hematologia e Hemoterapia da Bahia (HEMOBA), Salvador (BA), Brasil;

${ }^{4}$ Fundação de Hematologia e Hemoterapia da Bahia (HEMOBA), Salvador (BA), Brasil;

${ }^{5}$ In memorian. Instituto Brasileiro de Oftalmologia e Prevenção a Cegueira (IBOPC) Salvador (BA), Brasil; Escola de Medicina e Saúde Pública da Bahia/Fundação para o Desenvolvimento das Ciências da Bahia - EBMSP/FBDC - Salvador (BA), Brasil;

${ }^{6}$ Escola de Medicina e Saúde Pública da Bahia/ Fundação para o Desenvolvimento das Ciências da Bahia - EBMSP/FBDC - Salvador (BA), Brasil; Centro de Pesquisas Gonçalo Moniz- Fundação Oswaldo Cruz - (CPqGM-Fiocruz)- Salvador (BA), Brasil;

${ }^{7}$ Centro de Pesquisas Gonçalo Moniz - Fundação Oswaldo Cruz- (CPqGM-Fiocruz) - Salvador (BA), Brasil; Departamento de Análises Clinicas e Toxicológicas, Faculdade de Farmácia, Universidade Federal da Bahia (FF/UFBA) Salvador (BA), Brasil.
}

There is no conflict of interests in this work. 


\section{INTRODUCTION}

$\mathbf{T}$ The sickle cell hemoglobin (HbS) is characterized by a single nucleotide change $(\mathrm{G} \underline{\mathrm{AG}} \rightarrow \mathrm{GTG})$ in the sixth codon of the $\beta$-globin gene, which leads to a valine instead of glutamine in the sixth position of the $\beta$-globin chain. ${ }^{(1)}$

Because of its decreased solubility under deoxygenated conditions, hemoglobin S polymerizes in red blood cells, forming a highly ordered fiber aggregates that distort the cells' shape into an elongated forms. The polymer makes reversible and irreversible changes in sickle cell erythrocytes and is responsible for the sickle cell phenotype, including the homozygous state of $H B S S$ and heterozygous combinations such as $H B S C$ and HBS- $\beta$ thalassemia that have a less severe manifestations than those found in sickle cell anaemia patients. The sickle cell trait $(H B A S)$ is an exception and is not considered a sickle cell disease since the carriers do not have any clinical manifestations. ${ }^{(1)}$

The overall frequency of $\mathrm{HbS}$ is high worldwide, and in Brazil its distribution is heterogeneous. In Northeastern Brazil, mainly in Bahia, the population is a tri-racial mixture of Europeans (mostly Portuguese), Africans and indigenous. ${ }^{(2)}$ The frequency of $\mathrm{HbS}$ in the state of Bahia is the highest in Brazil, varying from 4.5 to $14.7 \%$ in several population groups studied. ${ }^{(3)}$

The sickle cell disease is characterized by a variety of clinical abnormalities frequently linked to hemolytic anaemia and vaso-occlusive processes, which are responsible for causing pain and other clinical features such as retinopathy. ${ }^{(1,4)}$

Ocular lesions results from stasis and occlusion of the small eye vessels by sickled erythrocytes. Transient dark red spots, representing plugs of sickled erythrocytes within superficial capillaries can be seen on the surface of the optic disc and conjunctiva. Vaso-occlusive disease of the retina can be responsible for nonproliferative and proliferative ocular changes. The nonproliferative lesions consist of ocular lesions such as a "salmon patches", vessel tortuosity, "black sunbursts", iridescent spots and angioid streaks that characterize hemorrhagic, infarctive, and resolving lesions of sickle retinopathy. ${ }^{(1)}$ Proliferative ocular lesions can result in partial or total loss of vision and are classified into different clinical stages. Stage I is characterized by arteriolar obstruction; stage II, by arteriovenous anastomoses; stage III, by neovascularization; stage IV, by vitreous hemorrhage and stage $\mathrm{V}$, by retinal detachment. ${ }^{(5)}$

Despite the high prevalence of sickle cell disease in Bahia and the high frequency of ocular changes in sickle cell disease patients, there have been no studies of these alterations with sickle cell retinopathy in Bahia, a state with African ethnic characteristics. ${ }^{(2)}$ We therefore consider important to characterize the ocular lesions found among sickle cell patients from northeast Brazil.

\section{$\underline{\text { Methods }}$}

This study was approved by the Oswaldo Cruz (Research Foundation's Human Research Ethics Committee), and informed consent was obtained in accordance with ethical principles and the Helsinki Declaration of 1975, and by the Brazilian resolution 196/ 96, of the Ministry of Health, Law 6,638/79 and Normative Resolution 04/97. Ophthalmologic examinations were carried out, and peripheral blood samples were collected only after signed informed consent was obtained.

The cross-sectional study involved a group of 146 (292 eyes) sickle cell patients (90 HBSS and 56 HBSC) from the State of Bahia in northeast Brazil and was carried out between july, 2002, and april, 2006.

The patients were selected among those attending the hematology ambulatory at the Bahia Foundation of Hematology and Hemotherapy (HEMOBA), a reference center attending to sickle cell disease patients who are seen in routinely visits. Patients were then sent to the Brazilian Institute of Ophthalmology and Blindness Prevention (IBOPC) for an ocular examination, including fundus biomicroscopy, indirect binocular ophthalmoscopy and fluorescein angiography when the retinopathy could not be adequately characterized solely by means of a fundoscopic examination. We observed the following in the fundoscopic examination: vascular tortuosity, alterations of papila, "salmon patches", angioid streaks and iridescent spots. The pathologic classification of fundoscopic alterations as proliferative was based on Goldberg's five-stage groups; stage I - peripheral arteriolar occlusions, stage II - peripheral arteriovenous anastomoses, stage III - preretinal neovascularization, stage IV - vitreous hemorrhage and stage $\mathrm{V}$ - retinal detachment.

Patients presenting with proliferative retinopathy were separated by age and classified as severe when displaying stages III to $\mathrm{V}$ when retinal neovascularization was seen. The hemoglobin pattern was confirmed at the Pathology and Molecular Biology Laboratory of Fiocruz and UFBA using High Performance Liquid Chromatography (HPLC-VARIANTI/BIO-RAD, CA, USA).

EpiInfo software for Windows, version 3.3.2 was used 
to store and analyze data. The Chi-squared Pearson's test or the Fisher's exact test was used when necessary to compare both groups of hemoglobinopathy carriers. A $p$-value of less than 0.05 was considered statistically significant.

\section{RESULTS}

The number of sickle cell disease patients enrolled in the study was 146 (292 eyes): 90 (61.6\%) with sickle cell anemia or HBSS and $56(38.4 \%)$ with $H B S C$ disease. The majority of these patients $(58.9 \%)$ were from Salvador, and the others came from other cities in the state. Overall, the patients had an average age of 26.7 (+11.6) years. The $H B S S$ patients group had an average age of 26.7 (+10.1) years and the $H B S C$ group had an average age of $26.9(+13.9)$ years. Eighty-four $(57.5 \%)$ were women, and $62(42.5 \%)$ were men. Among the HBSS patient group, there were $39(43.3 \%)$ men and 51 (56.7\%) women, while among the $H B S C$ group, there were 23 $(41.1 \%)$ men and 33 (58.9\%) women. Statistically nonsignificant differences were found when comparing the age $(\mathrm{p}=0.625)$ of the HBSS and HBSC patients. There were no significant differences in gender $(\mathrm{p}=0.923)$ when comparing both patient groups studied.

Two $H B S C$ disease patients had an intraocular pressure $\geq 20 \mathrm{mmHg}$; however, no overall change in intraocular pressure was observed among the different patient groups. Visual acuity was $20 / 20$ or $20 / 25$ for the best eye in 133 patients, corresponding to $91.1 \%$ of the total number of cases.

Age-related ocular lesions, including nonproliferative and proliferative lesions, were very frequent among both groups of patients (HBSS and $H B S C$ ). Table 1 shows the ocular lesion distribution across six age groups. The $H B S S$ group had more ocular changes in the age range of 20-39. In the $H B S C$ group of patients these changes became more frequent in the age range of 40 to more than 50 years.

Vascular tortuosity and "black sunbursts" were the most frequent fundoscopic ocular lesions found in both sickle cell disease groups (HBSS and HBSC). Table 2 shows that the vascular tortuosity percentage was similar in both sickle cell disease patients' groups. The "black sunburst" was more frequent in the HBSC disease group. The frequency of "salmon patches" and angioid streaks, however, was low in both groups, and the disc-shaped signal and iridescent spots were only found in the HBSS group.

In both the HBSS and HBSC disease groups, there were patients with proliferative ocular lesions; however, the $H B S C$ group had more proliferative ocular lesions than the HBSS group.

The $H B S S$ group had more severe ocular disease in the age range of 30-39 than the HBSC group. Table 3 shows the distribution of proliferative ocular lesions across six age groups related to stages I to V and III to V. The $H B S S$ group had the highest frequency of proliferative changes, mainly in the age range of 20-39. The HBSC patient group had more ocular changes in the age range of 40-49. Table 4 shows that the HBSC group had more cases of proliferative ocular lesions per eye than the HBSS group. Figure 1 shows fluorescein angiography of peripheral arteriolar occlusions, peripheral arteriovenous anastomoses, preretinal neovascularization and extensive capillary non-perfusion from a 31-year-old woman with sickle cell anemia (HBSS).

\section{Discussion}

Several ocular changes were observed in the studied patient groups; however, no change in visual acuity was found, as previously reported. ${ }^{(5-10)}$

With regard to the fundoscopic lesions, vascular tortuosity and "black sunbursts" were the most frequent changes identified, corroborating previous Brazilian studies. ${ }^{(7-10)}$ The overall frequency of vascular tortuosity was similar in both patient groups ( $H B S S$ and $H B S C$ ), as previously described. ${ }^{(10,11)}$ The "black sunburst" lesion was seen in both groups, although its frequency in $H B S C$ patients was much lower than that described in other studies. ${ }^{(10,12,13)}$ The low frequency of other ocular lesions such as the disc sign and iridescent spots could be attributed to their transient status and to the fact that they do not produce clinically visual impairment that requires serial follow-up testing. ${ }^{(14)}$

Proliferative retinopathies were significantly more frequent in the HBSC group than in HBSS group, as described previously. ${ }^{(1,7,15-17)}$ When the HBSC patients were stratified according to age, however, we observed two peaks of ocular changes, one between 10 and 19 years of age and another between 40 and 49 years of age that subsequently dropped sharply. This finding is in contrast to previous studies. ${ }^{(15,18,19)}$ Indeed, Fox et al. ${ }^{(18)}$ studied Jamaican patients and observed that ocular proliferative lesions increased with age in both genotypes. Interestingly, the HBSS patients had more severe proliferative changes (stages III to $\mathrm{V}$ ) between the ages of 10 to 19 years and 30 to 39 years when compared to the $H B S C$ group, characterizing an elevated frequency when compared with others studies. ${ }^{(20,21)}$ On the basis of 
our results, additional studies are warranted to determine if these findings are related to an increase of vasoocclusive crisis among these specific ages or with the presence of others biomarkers for assessing relative risk in these group of SCA patients.

This is the first study of ocular lesions among $H B S S$ and $H B S C$ patients from Bahia. The lower percentage of severe proliferative retinopathy found among $H B S S$ patients when compared to $H B S C$ patients could be attributed to auto infarction or a spontaneous regression of proliferative retinopathies, a phenomenon described in sickle cell disease. ${ }^{(21)}$ A milder disease phenotype was previously described among these patients, ${ }^{(22,23)}$ protecting against the early vessel occlusion described in $H B S S^{1}$ and contributing to proliferative lesion development among the older patients. In addition, the age-related variation in proliferative lesions observed in $H B S C$ patients could be related to more severe anemia, resulting in a decrease in blood viscosity. The results presented here show that sickle cell disease patients from Bahia could have specific risk factors for retinal vessel changes other that those described before. ${ }^{(24,26)}$

\section{Conclusion}

In conclusion, the ocular lesions described here could help to define the clinical and ophthalmologic protocols of $H B S S$ and $H B S C$ patient's follow-up in specific ages. The presence of proliferative ocular alterations are a well documented cause of blindness and the knowledge of the most prevalent ocular alterations and age risk of these in $H B S S$ and $H B S C$ patients will be important to establish ophthalmologic follow-up protocols, preventing a severe visual loss. Further studies, including the association between ocular lesions and hematological, environmental and genetic factors - in a larger number of $H B S S$ and $H B S C$ patients in Brazil should contribute to improving patient quality of life, bringing new knowledge of ophthalmologic alterations among these patients.

\section{Acknowledgements}

We thank the medical staff of the institutions where the study was developed and parents and patients whose gave their informed consent to participate in the study. This study was supported by CNPq, DECIT contract grant numbers: 305427/2007-7 (MSG); and 409800/20066 (MSG);FAPESB / UNESCO, contract grant number: 013/03 (MSG).

\section{Resumo}

Objetivo: O presente estudo teve como objetivo descrever as alterações oculares em pacientes portadores de doença falciforme, na Bahia, um estado do Nordeste, que tem a maior prevalência da doença no Brasil. Métodos: Nós conduzimos um estudo de corte transversal em um grupo de 146 (292 olhos) pacientes com Doença Falciforme (90 HBSS e 56 HBSC). Para exame oftalmológico foi realizada oftalmoscopia binocular indireta complementada pela retinografia fluorescente para detecção de lesões retinianas decorrentes da Doença Falciforme. Resultados: As lesões mais frequentemente encontradas foram o aumento da tortuosidade vascular e "black sumburst" Retinopatia proliferativa foi encontrada em 22 (12,2\%) olhos de pacientes HBSS e $25(22,3 \%)$ olhos de pacientes HBSC (OR=2.06; CI95\%: 1.5-4.06, $p=0.022$ ); essa frequência foi maior entre os pacientes HBSS com idade entre 20 - 39 anos, enquanto que nos pacientes HBSC foi maior nos acima de 40 anos (35.7\% e 42.8\%), decaindo abruptamente após essa idade. Conclusão: Retinopatia proliferativa foi descrita por volta dos dez anos de idade em ambos os grupos. A prevalência da retinopatia falciforme proliferativa pode resultar em cegueira e o conhecimento das alterações oculares mais prevalentes e idade de risco destas em pacientes com Doença Falciforme será importante para estabelecer um protocolo de acompanhamento oftalmológico, para prevenir um dano visual clinicamente grave, aumentando a qualidade de vida destes pacientes.

Descritores: Anemia falciforme; Doença de hemoglobina SC; Traumatismos oculares; Doenças retinianas

\section{REFERENCES}

1. Ohene-Frempong K, Steinberg MH. Clinical aspects of sickle cell anemia in adults and children. In: Steinberg MH, Forget BG, Higgs DR, Nagel RL, editors. Disorders of hemoglobin: genetics, phatophysiology and clinical management. New York: Cambridge University Press; 2001. p.611-670.

2. Azevêdo ES, Fortuna CM, Silva KM, Sousa MG, Machado MA, Lima AM, et al. Spread and diversity of human populations in Bahia, Brazil. Hum Biol. 1982; 54(2): 329-41.

3. Azevêdo ES, Alves AF, Da Silva MC, Souza MG, Muniz Dias Lima AM, Azevedo WC. Distribution of abnormal hemoglobins and glucose-6-phosphate dehydrogenase variants in 1200 school children of Bahia, Brazil. Am J Phys Anthropol. 1980; 53(4):509-12.

4. Vilela RQ, Bandeira DM, Silva MA. Alterações oculares nas doenças falciformes/ Ocular complications in sickle cell disease. Rev Bras Hematol Hemoter. 2007; (29):285-7.

5. Goldberg MF. Classification and pathogenesis of proliferative sickle cell retinopathy. Am J Ophthalmol. 1971;71(3)):649-65. 
6. Condon PI, Serjeant GR. Ocular findings in hemoglobin SC disease in Jamaica. Am J Ophthalmol. 1972;74(5):921-31..

7. Bonanomi MT, Cunha SL, Araújo JT. Funduscopic alterations in SS and SC hemoglobinopathies. Study of a Brazilian population. Ophthalmologica. 1988;197(1):26-33.

8. Popma SE. Ocular manifestation of sickle hemoglobinopathies. Clin Eye Vis Care. 1996;8(2): 111-7.

9. Akinsola FB, Kehinde MO. Ocular findings in sickle cell disease patients in Lagos. Niger Postgrad Med J. 2004;11(3):203-6.

10. Garcia CA, Fernandes MZ, Uchôa UB, Cavalcante BM, Uchôa RA. Achados fundoscópicos em crianças portadoras de anemia falciforme no Estado do Rio Grande do Norte. Arq Bras Oftalmol. 2002;65(6):615-8.

11. Fox PD, Minninger K, Forshaw ML, Vessey SJ, Morris JS, Serjeant GR. Laser photocoagulation for proliferative retinopathy in sickle haemoglobin C disease. Eye (Lond). 1993; 7(Pt 5): 703-6.

12. Moriarty BJ, Acheson RW, Condon PI, Serjeant GR. Patterns of visual loss in untreated sickle cell retinopathy. Eye (Lond). 1988; 2(Pt3): 330-5.

13. Welch RB, Goldberg MF. Sickle-cell hemoglobin and its relation to fundus abnormality. Arch Ophthalmol. 1966; 75(3):353-62.

14. Condon PI, Serjeant GR. Ocular findings in elderly cases of homozygous sickle-cell disease in Jamaica. Br J Ophthalmol. 1976; 60(5):361-4.

15. Goldbaum MH, Jampol LM, Goldberg MF. The disc sign in sickling hemoglobinopathies. Arch Ophthalmol. 1978; 96(9): 1597-600.

16. Oliveira FV, Aihara T, Cançado RD. Alteraçöes fundoscópicas nas hemoglobinopatias SS e SC. Arq Bras Oftalmol. 1996;59(3):234-8.

17. Moraes Junior HV, Araújo PC, Brasil OF, Oliveira MV, Cerqueira V, Turchetti R. Achados oculares em doença. Rev Bras Oftalmol. 2004; 63(5/6):299-302.

18. Fox PD, Dunn DT, Morris JS, Serjeant GR. Risk factors for proliferative sickle retinopathy. Br J Ophthalmol. 1990; 74(3):172-6.

19. Gagliano DA, Goldberg MF. The evolution of salmon-path hemorrhages in sickle cell retinopathy. Arch Ophthalmol. 1989; 107(12):1814-5.
20. Clarkson JG. The ocular manifestations of sickle-cell disease: a prevalence and natural history study. Trans Am Ophthalmol Soc. 1992; 90:481-504.

21. Bonanomi MT. Neovascularizaçäo da retina em hemoglobinopatia SC e hemorragia. Arq Bras Oftalmol. 1997; 60(1):24-33.

22. Downes SM, Hambleton IR, Chuang EL, Lois N, Serjeant GR, Bird AC. Neovascularizaçäo da retina em hemoglobinopatia. Ophthalmology. 2005; 112(11):1869-75.

23. Lyra IM, Goncalves MS, Braga JA, Gesteira Mde F, Carvalho MH, Saad ST, et al. Clinical, hematological, and molecular characterization of sickle cell anemia pediatric patients from two different cities in Brazil. Cad Saude Publica. 2005;21(4):1287-90.

24. Goncalves MS, Bomfim GC, Maciel E, Cerqueira I, Lyra I, Zanette A et al. BetaS-haplotypes in sickle cell anemia patients from Salvador, Bahia, Northeastern Brazil. Braz J Med Biol Res. 2003; 36(10):1283-8.

25. Lima CS, Rocha EM, Silva NM, Sonatti MF, Costa FF, Saad ST. Risk factors for conjunctival and retinal vessel alterations in sickle cell disease. Acta Ophthalmol Scand. 2006; 84(2): 234-41.

26. Diallo JW, Sanfo O, Blot I, Meda N, Sawadogo P, Quedraogo A, Simporé J. [Epidemiology and prognostic factors for sickle cell retinopathy in Ouagadougou (Burkina Faso). J Fr Ophtalmol. 2009; 32(7):496-500.

\section{Corresponding authors: Marilda Souza Goncalves Rua Waldemar Falcão, 121, Candeal CEP 40296-710 - Salvador (BA), Brazil Phone: 55-71-3176-2226}

Fax: 55-71-3176-2327

E-mail: mari@bahia.fiocruz.br; daysecury@ig.com.br 